\title{
LA ICONOGRAFÍA DE SAN MIGUEL EN LAS SERIES ANGÉLICAS
}

\section{THE ICONOGRAPHY OF SAN MIGUEL IN THE SERIES ANGELIC}

\author{
Mario Ávila Vivar \\ Centro de Conservación y Restauración de Castilla-La Mancha. España \\ marioavilavivar@gmail.com
}

Durante los siglos XVI y XVII surgieron dos nuevas propuestas iconográficas para la representación de San Miguel arcángel, que no recogen los manuales de iconografía. Una de ellas, elaborada por Martín de Vos, le muestra con la mano derecha aureolada por el sol, y portando una palma en la mano izquierda. La otra, desarrollada en Andalucía por Francisco Pacheco y los seguidores de Zurbarán, le representa con indumentaria militar del siglo XVI, sosteniendo una rodela y un bastón de mando. Ambas imágenes responden a nuevos enfoques en la devoción de San Miguel propiciadas por la Contrarreforma. Las dos fueron incorporadas a las series angélicas, y alcanzaron gran popularidad tanto en España como en América.

Palabras clave: San Miguel arcángel. Angelología del Barroco. Series angélicas. Alegoría. Literatura angélica.

During the 16th and 17th centuries two new iconographic designs appeared for the representation of San Miguel archangel that did not reflect the manuals of iconography. One of which, elaborated by Martín de Vos, shows him with his right hand ringed by the sun, and carrying a palm tree leaf in his left hand. The other, developed in Andalucía by Francisco Pacheco and the followers of Zurbarán, represented San Miguel with military attire of the 16th century, holding a shield and baton. Both images respond to new focuses in the devotion of San Miguel favored by the Counter-reform. Both were incorporated in the angelic series and achieved great popularity both in Spain and America. erature.

Keywords: San Miguel archangel. Anthology of Baroque. Angelic series. Iconography. Angelic lit-

La representación de San Miguel en las series angélicas podría dividirse en dos grandes grupos. En la mitad de las series figura con su imagen tradicional, con espada o lanza derrotando al demonio. Así se representa en las series españolas 
del monasterio de Santa Clara de Carmona (Sevilla), Chera (Guadalajara) ${ }^{1}$, Ezcaray (Rioja), y Borriol (Castellón), y en las colombianas de Sopó y Santa Clara de Bogotá. Sin embargo, en la otra mitad figura con atributos que no recogen los manuales de iconografía. En las tres que realizó Bartolomé Román para los monasterios de la Encarnación y Descalzas Reales de Madrid, en la de la iglesia de San Pedro de Lima, y en el cuadro del Museo Provincial de Guadalajara, resto de alguna serie, fue representado con la mano derecha elevada hacia el cielo y aureolada por el sol, y portando una palma en la mano izquierda ${ }^{2}$. Y en el resto de las series, casi todas ellas realizadas por pintores andaluces, se representa con indumentaria militar del siglo XVI, sosteniendo una rodela y un bastón de mando. Así figura en las series del monasterio de San José y San Roque de Aguilar de la Frontera (Córdoba), catedral de Jaén, Hospital del Pozo Santo (Sevilla), monasterio de San Jerónimo de Granada, iglesia parroquial de Tartanedo (Guadalajara), iglesia de Santa Bárbara de Tunja (Colombia) y monasterio de la Concepción de Lima (Perú) $)^{3}$.

El prototipo del modelo que representó Bartolomé Román fue creado por Martin de Vos hacia 1580, y grabado por Hieronymus Wierix en 1584. Martin de Vos representó a San Miguel como un atlético joven de carácter hermafrodita, ya que simula un pecho de mujer y otro de hombre. Su indumentaria recrea la de un emperador romano vestido con traje militar de gala, con coraza anatómica, túnica y paludamento. El peto va adornado con el sol, la luna y las estrellas, porque San Miguel gobierna el universo. Como mandan los cánones, tiene cabellos rubios rizados y unas magníficas alas de águila. Y para poner de manifiesto que es el Príncipe de los ángeles, sobre su cabeza se representan los nueve coros angélicos, y en cada uno de los flecos del faldellín, la figura de un ángel. Cabezas de ángeles luce también en el ribete del cuello, en la cintura y en los broches de brazos y piernas. Como atributos, en su mano izquierda sostiene una palma, y su mano derecha aparece elevada y nimbada por un sol donde figura escrito su grito de guerra: Quis ut Deus. Con su pierna izquierda pisa al demonio, en este caso una mujer con alas de ángel y cola de serpiente, que oculta sus pechos con los brazos a la mirada del arcángel. Y a los pies del grabado de Wierix, figura una inscripción que condena el pecado de soberbia del demonio: Grandia spirantes summo de

1 ÁVILA VIVAR, Mario: “Ángeles arcabuceros españoles. La serie de Chera (Guadalajara)”, Cuadernos de Arte e Iconografía, 46, 2014, pp. 503-521.

2 ÁVILA VIVAR, Mario: "Relaciones del P. Jerónimo Gracián con las series angélicas de los monasterios reales madrileños. Origen y evolución de las series de los siete Príncipes de los Ángeles", Reales Sitios, 189, 2011, pp. 52-72.

3 ÁVILA VIVAR, Mario: Angelología Barroca. Las Series Angélicas, Toledo, 2016. GONZÁLEZ ESTÉVEZ, Escardiel: "De fervor regio a piedad virreinal. Culto e iconografía de los Siete Arcángeles”, SEMATA, Ciencias Sociais e Humanidades, 24, 2012, pp. 111-132. 
vertice coeli rex summus poena praecipitavit acri. (A los que aspiraban a cosas elevadas el rey Supremo los precipitó desde el vértice del cielo con una dura pena).

El modelo de Martín de Vos también fue llevado a la estampa, entre otros grabadores belgas, por Gerard de Jode en su Thesaurus sacrarum historiarum... (1585), formando parte de tres triadas de ángeles: Michael, Uriel, Raphael; Gabriel, Jophiel y Raziel; y Teadkiel, Piel y Mittaron; los ángeles que cabalistas del siglo XVI y XVII, como Johannes Reuchlin, Cornelius Agrippa y Athanasius Kircher, asociaban a los patriarcas y a los profetas bíblicos (Figuras 1 y 2).

¿Qué peculiaridades de San Miguel querían resaltar los manieristas belgas con esta iconografía? Los atributos que porta San Miguel son los mismos que ostenta la alegoría de la Verdad en la primera edición ilustrada de la Iconología de $\mathrm{Ripa}^{4}$, donde figura como una mujer desnuda que pisa el globo terráqueo, y sostiene en su mano derecha un sol, y en la izquierda un libro y una palma. El texto de Ripa dice:

"VERDAD

Una bellísima mujer desnuda, tiene en la mano derecha elevada el sol, al cual mira...

Se representa completamente desnuda, porque su naturaleza es la simplicidad... Sostiene el sol para significar que ama la luz, que ella es la propia luz.... También puede decirse que mira al sol, o sea a Dios, sin el cual no hay luz ni verdad alguna, puesto que solo él es la verdad en si mismo...

El libro abierto, muestra que en los libros se encuentra la verdad de las cosas, realizándose en ellos por lo tanto el estudio de la Ciencia.

Con el ramo de palma puede significarse su vigor y su fuerza, y del mismo modo que la palma no cede con el peso de las cosas, la Verdad no cede ante las cosas contrarias.... Además significa la fortaleza y victoria, pues Esquines sostiene contra Timarco que la Verdad posee tanta fuerza que sale victoriosa frente a todas las opiniones humanas...

El mundo bajo sus pies indica que vale más que todas las cosas de este mundo, es por lo que Menandro dijo de ella que era ciudadana del cielo, y que sólo se goza en la morada de Dios".

La alegoría de la Verdad también aparecía en libros de emblemas y jeroglíficos como una mujer vestida con larga túnica, acompañando al Amor y al Honor como símbolo de Fidius Deus, la primera virtud teologal que la iglesia describe como una luz divina por la cual somos capaces de reconocer a Dios. Así figura en los Emblemas de Alciato (Lion, 1549), y en Hieroglyphica de Pietro Valeriano (Basilea, 1556). ¿Pretendió Martín de Vos identificar a San Miguel con la alegoría de la Verdad, en cuanto defensores de la luz divina y de la Fe? Es posible, pero como su fuente iconográfica no fueron los citados libros de emblemas, donde la Verdad no ostenta atributos, ni la Iconología de Ripa, publicada posteriormente

${ }^{4}$ RIPA, Cesare: Iconología, Roma, 1603, pp. 499-501. 
a la pintura del artista belga, la representación de la Verdad portando el sol y la palma debió conocerla Martín de Vos por otros medios.

Uno de ellos pudo ser a través de las representaciones de la Calumnia de Apeles, que, siguiendo la descripción que hizo Lucano, recrearon los artistas italianos del Quattrocento. Como hizo Botticelli, quien representó a la Verdad como una bellísima mujer desnuda señalando a Dios o al sol con su mano derecha. Pero es bastante probable que la fuente del San Miguel de Martín de Vos fuese Durero. Él también dibujó la Verdad como una mujer lujosamente vestida, portando el sol sobre una copa en su mano derecha ${ }^{5}$. Pero su fuente directa debió ser el grabado de Durero de Sol-Apolo y Diana, donde representa a Apolo como al dios Sol, sosteniendo el disco solar en la mano derecha, y portando un cetro en la izquierda. Según Panofsky ${ }^{6}$, Durero utilizó dibujos italianos del Apolo del Belvedere para elaborar diversas imágenes; entre ellas esta de Sol-Apolo, la de Apolo Medicus, la de Adán, la de Cristo resucitado, e incluso la del Sol Iustitiae; imágenes que evidenciarían la asociación de los cultos solares paganos y el Sol invictus de la Antigüedad tardía, con el culto de Cristo.

Y si Durero transformó la imagen de Apolo en la de Cristo, también Martín de Vos pudo utilizarla para representar a San Miguel, ya que con ambos fue asociado Apolo por el cristianismo primitivo. Puesto que si San Miguel derrotó al demonio, Apolo mató a la serpiente Pitón, que perseguía a su madre e impedía su nacimiento, del mismo modo que el dragón perseguía a la mujer apocalíptica para impedir el nacimiento del Hijo de Dios. Y del mismo modo que los primeros cristianos veneraban a San Miguel como médico y como protector ante el demonio, Apolo fue idolatrado por ser el dios de la medicina, y protector contra las plagas, las enfermedades y las fuerzas malignas. Y conviene resaltar que Apolo era hijo de Zeus, y que si los católicos consideraron a San Miguel similar a Dios (Quien es como Dios), los luteranos y calvinistas le reconocieron directamente Hijo de Dios. Y quizás no fuese una casualidad que Martin de Vos elaborase su imagen de San Miguel, precisamente cuando los calvinistas gobernaron Amberes. Por otra parte, parece ser que Martin de Vos formaba parte de la Familia Charitatis, una secta religiosa derivada del misticismo renano, que consideraba que las Escrituras eran solamente alegorías. Su centro difusor fue la imprenta de Plantino, con quien colaboraban asiduamente otros miembros de la Familia, como

${ }^{5}$ VV.AA.: Durero. Obras maestras de la Albertina, Madrid, 2005, pp. 297-299. La Calumnia de Apeles también fue representada en un friso en el Ayuntamiento de Nuremberg por el taller de Durero en 1521, que aunque perdido en la Segunda Guerra Mundial, se conserva en un dibujo del pintor de 1522.

${ }^{6}$ PANOFSKY, Erwin: El significado de las artes visuales, Madrid, 1987, pp. 263-281. 
Wierix y Arias Montano, a quien dedicó Wierix su grabado de San Miguel $^{7}$ (Figuras 3,4 y 5).

Sea como fuere, si Martin de Vos y/o sus asesores elaboraron una nueva iconografía de San Miguel a partir de las alegorías de la Verdad y del Sol-Apolo de Durero, podemos deducir que su intención fue ensalzar la dimensión divina del arcángel, y presentarle como al defensor de la Fe y de la Verdad, exhibiendo su Victoria frente a las mentiras del demonio, asistido por la Fortaleza simbolizada en la palma, y como gobernador del Cielo y Príncipe de los coros angélicos. Se trata sin duda de una representación bastante intelectualizada, fiel al gusto por la alegoría del siglo XVI, que se convirtió en la nueva propuesta iconográfica de San Miguel de muchos artistas de finales del Renacimiento y del Barroco, tanto en España como en América (Figuras 6 y 7).

La otra imagen de San Miguel que le muestra vestido de militar con casco emplumado, y portando una rodela y un bastón de mando, es la que predomina en el segundo grupo de series angélicas. Se suele considerar como prototipo de esta iconografía, el modelo atribuido a Zurbarán que se conserva en la colección Banco Central Hispano ${ }^{8}$, donde se representa al arcángel sosteniendo una espada flamígera con la inscripción Quis sicut Deus en su hoja. De nuevo surgen las mismas preguntas que en el caso del San Miguel de Martín de Vos. ¿Quién, cuando y donde se realizó este cambio en la iconografía del arcángel? ¿Por qué razón los pintores andaluces del barroco desarrollaron esta nueva iconografía y tomaron el modelo de Zurbarán como prototipo? ¿Por qué cambiaron su espada o su lanza tradicional por un bastón de mando? La respuesta a estas preguntas la obtuve en la literatura angélica y en los tratados artísticos del Barroco.

Es bastante probable que esta novedosa iconografía la desarrollaran los discípulos de Zurbarán, a quien se atribuye la mayoría de las series angélicas andaluzas; entre ellos, Bernabé de Ayala y los hermanos Polanco ${ }^{9}$. Al primero se atribuyen dos ejemplares de San Miguel de los conventos del Cristo de la Victoria de Serradilla (Cáceres), y de Santa Clara de Cáceres, que siguen en todo el modelo de la colección $\mathrm{BCH}$, y ya portan un bastón de mando sobre los hombros ${ }^{10}$.

${ }^{7}$ Este aspecto ha sido analizado en https://agorasimposio.wordpress.com/ por Ángel Almazán en su blog, Vida y Pensamientos, a lo largo de diversas publicaciones en 2013.

${ }^{8}$ DÍAZ PADRÓN, Matías: "Pintura de los siglos XVI y XVII", en Colección Central Hispano. Del Renacimiento al Romanticismo, Madrid, 1996, pp. 52-53.

9 FERNÁNDEZ LÓPEZ, José: "Los ángeles y los Arcángeles de la Capilla de San Miguel de la Catedral de Jaén", Laboratorio de Arte, 8, 1995, pp.157-173. FERNÁNDEZ LÓPEZ, José: Programas iconográficos de la pintura barroca sevillana del siglo XVII, Sevilla, 1991, pp. 205-218. LARA ARREBOLA, Francisco: "Bernabé de Ayala y la serie de ángeles del monasterio de San José y San Roque de Aguilar de la Frontera", Boletín de la Real Academia de Córdoba, 101,1980, pp. 195-211.

${ }^{10}$ GARCÍA MOGOLLÓN, Florencio Javier: "La colección pictórica del convento del Cristo de la Victoria de Serradilla”, Norba. Revista de arte, geografía e historia, 1, 1980, p. 39. 
Pero en mi opinión, quien ideó e inició esta novedosa iconografía de San Miguel fue Francisco Pacheco, quien le representó portando el bastón en el Juicio universal que había realizado en 1614 para el convento de Santa Isabel de Sevilla. El arcángel figura en el centro de la composición de la parte terrena, separando a los justos de los pecadores, con un bastón de mando en su mano derecha, recreando un grabado de Gerard de Jode en Siete Obras de Misericordia (Amberes, 1585), también sobre un dibujo de Martín de Vos. El Juicio universal fue comentado exhaustivamente por Pacheco en el libro segundo de su Arte de la Pintura, donde dedicó dos capítulos a justificar su iconografía, ya que de alguna forma su Juicio Universal replanteaba la cuestionada representación del mismo tema de Miguel Ángel, tan criticado por la Contrarreforma. En su realización se asesoró de numerosas personas versadas en los aspectos doctrinales y teológicos que suscitaba la obra, e incluso recabó dos Aprobaciones firmadas por Francisco de Medina y Alonso Gómez de Rojas. Y así, argumenta que

"El San Miguel hace figura de capitán general, armado a lo romano de su coracina y grevas, con morrión de varias plumas, con bastón en la mano derecha y espada ceñida, con ademán airoso y bizarro, y ropajes de lindos colores. En ponerlo aquí se siguió el voto del maestro Francisco de Medina, por los apellidos y oficios que tiene. Llámase Prepósito y Príncipe de la Iglesia, primado del cielo, cabeza de todos los ángeles, alférez mayor del Supremo Emperador, capitán fortísimo recibidor de las almas y juez de ellas, vencedor del gran dragón, y a quien toca acabar la batalla que comenzó en el cielo, encerrando al demonio para siempre, y executando el mandato y decreto del eterno juez. Y si es capitán de la Iglesia, tenga bastón y cargo de los exércitos della, como dice un docto moderno. Llámanse los ángeles soldados, militia coelestis, del Señor de los exércitos, y dellos es capitán S. Miguel, de manera que le toca, justamente, hacer este oficio por muchas causas y razones." ${ }^{11}$ [El subrayado es mío] (Figuras 8 y 9).

En nota al margen, Pacheco indica que la cita de ese "docto moderno" la ha tomado de "Fray Gerónimo Gracián, Libro $2^{\circ}$ de S. Josef, cap. $1^{\circ} 16^{12}$. La cita textual es la siguiente: "Y quando llaman a S. Miguel Capitán de la Iglesia, le dan el bastón, y cargo, de los exercitos della"13. Es posible que la idea de representarlo con el bastón de mando partiese de Francisco de Medina, que como dice Pacheco le asesoró en la representación del arcángel, ya que era un hombre

${ }^{11}$ PACHECO, Francisco: El Arte de la Pintura, (Edición, introducción y notas de Bonaventura Bassegoda i Hugas), Madrid, 2001, pp. 313-314.

${ }^{12}$ La obra es Summario de las excelencias del glorioso S. Ioseph esposo de la Virgen Maria / recopilado de diuersos auctores por... Fr. Geronimo Gracian de la Madre de Dios..., publicado en Roma en 1597.

13 GRACIÁN DE LA MADRE DE DIOS, Jerónimo: Obras del P. maestro F. Geronymo Gracian de la Madre de Dios, de la orden de N. Señora del Carmen...: En Madrid: por la viuda de Alonso Martin, 1616, p. 241. 
cultísimo que poseía una excelente biblioteca consultada por el pintor en numerosas ocasiones ${ }^{14}$. Sea como fuere, el caso es que la propuesta de Jerónimo Gracián y la iniciativa de Pacheco tuvieron éxito, y la imagen de San Miguel con bastón de mando se incorporó a numerosos cuadros, incluidas las series angélicas, y se extendió por España y América.

Todos estos cambios en la representación tradicional de San Miguel, hay que inscribirlos en la búsqueda de nuevas iconografías, más acordes con las indicaciones del concilio de Trento, que obligaba a los artistas a incorporar en sus obras la nueva doctrina. La imagen de San Miguel que el arte de la Edad Media había legado a los artistas, era la de signífero, portando la cruz de Cristo; la de psicopompo, pesando las almas en una balanza, y la de vencedor del demonio, al que pisaba en el suelo mientras le amenazaba con una espada o con una lanza. Sin embargo, las balanzas se fueron abandonando tras el concilio de Trento, porque como argumentaba fray Hortensio Félix Paravicino, "Y en verdad, que como se expurgan libros, sería bien expurgar pinturas... San Miguel no pesa unos con otros, sino buenas, y malas obras, culpas, y satisfacciones..." 15 Como signífero y como vencedor del demonio se siguió representando, pero la Iglesia tridentina aceptó de buen grado la nueva imagen del arcángel que le mostraba como defensor de la Verdad, y esta otra que exaltaba su auctoritas. Porque seguramente para la mentalidad cortesana de la sociedad del Antiguo Régimen, era más importante resaltar su jerarquía como Capitán General del ejército celestial, que su carácter guerrero. Y la auctoritas la simbolizada el bastón de mando, y no en la espada. Cayado, cetro, báculo y vara o bastón de mando es un símbolo tradicional del poder, que ostentaban los mandos religiosos, políticos y militares desde tiempos prehistóricos ${ }^{16}$. Con esos distintivos se representaban los faraones egipcios, los dioses y los héroes griegos, los emperadores romanos, los reyes medievales, los papas y los obispos, y con ellos se distinguía también a las altas jerarquías de la España barroca.

Y desde siempre fue considerado San Miguel la personalidad de mayor rango entre los cortesanos del rey del cielo. Su nombre aparece mencionado en el Libro de Daniel y en el Apocalipsis, como el "gran Príncipe" que defiende al pueblo de Dios del Anticristo, y como el jefe de los ángeles que expulsaron a Satanás

${ }^{14}$ CACHO CASAL, Marta P.: Pacheco y su Libro de Retratos, Sevilla, 2011.

15 INTERIÁN DE AYALA, Juan: El pintor christiano, y erudito, ó Tratado de los errores que suelen cometerse freqüentemente en pintar, y esculpir las Imágenes Sagradas. Dividido en ocho libros con un apéndice...; escrita en latín por...Juan Interián de Ayala...; y traducida en castellano por D. Luis de Durán y de Bastéro, Alacant: Biblioteca Virtual Miguel de Cervantes, 2001, Edició digital basada en l'edició de Madrid, por D. Joachin Ibarra..., 1782, Libro II, capítulo VI.

${ }^{16}$ CHEVALIER, Jean y GHEERBRANT, Alain: Diccionario de los símbolos, Barcelona, 1993, pp. 180-183. 
y a los ángeles rebeldes de cielo, cuando estos se rebelaron contra la Encarnación de Cristo. Estos hechos hicieron pensar a San Gregorio Magno y otros antiguos Padres de la Iglesia, que San Miguel, cuyo nombre significa Quien cómo Dios, o Quien es cómo Dios, era el ángel que la Biblia mencionaba como el "ángel de Yavhe", el ángel que reemplazaba a Dios en sus relaciones con los hombres, y el ángel que ejecutaba aquellas empresas para las que se requería un poder extraordinario. Y por ese motivo creyeron que fue San Miguel quien se encargó del cuidado y del gobierno de la Creación; quien expulsó a Adán y Eva del Paraíso y les reveló lo que acontecería en el mundo hasta el día del Juicio. Quien dio a Moisés las tablas de la Ley, envió las plagas a Egipto, separó las aguas del mar Rojo, guió a los israelitas a través del desierto, e impidió que el diablo se apoderara del cuerpo de Moisés. El ángel que conduce a las almas al Paraíso; el abanderado de los ángeles de Cristo que matará al Anticristo; quien dará la orden para que los muertos resuciten, quien evaluará las almas, y el signifero que presentará ante el Tribunal del cielo las arma Christi el día del Juicio ${ }^{17}$. Tales honores y prerrogativas determinaron que monarcas, papas y emperadores le tomaran por su protector. Ya que si San Miguel había sido el miles coelestis por excelencia, y el príncipe protector de la sinagoga, era lógico que también lo fuese de la Iglesia y del Imperio.

La devoción que la sociedad barroca profesaba a San Miguel, la expuso magníficamente el jesuita Juan Eusebio Nieremberg ${ }^{18}$, quien escribió un panegírico sobre el arcángel que recoge todo lo que se había escrito sobre él hasta el siglo XVII. El libro se lo dedicó a Felipe IV, a quien recuerda en el Prólogo que tanto la monarquía española como la casa de Austria se habían cimentado sobre el patrocinio del arcángel:

"SEÑOR... En dia de San Miguel fue aclamado por Cesar el primero que lo fue de la Casa de Austria. Y en dia de san Miguel fue aclamado por Catolico el primero que lo fue de los Reyes Godos. Dos grandes glorias tiene V.M. ser Cabeça de la Casa de Austria, y ser Sangre de los Godos. (...) Continuará este Principe de los Angeles su proteccion, continuando V.M. la devocion de sus mayores" ${ }^{\prime 1}$.

Como ya había intentado fray Severo de Tobar con Felipe III, Nieremberg trataba de convencer a Felipe IV de que el patrocinio de San Miguel era el mejor remedio para los males de España. Y su propuesta parece que fue bien acogida por el monarca, ya que el libro incluye una Carta del Consejo de su Magestad à todas las ciudades destos Reinos, fechada a 17 de marzo de 1643, en la que ordena se celebre la fiesta de San Miguel el 8 de mayo, con ayunos y procesiones a

17 VORÁGINE, Santiago de la: La Leyenda dorada, vol.2, Madrid, 2008, pp. 620-621.

18 NIEREMBERG, Juan Eusebio (S.I.): De la devocion y Patrocinio de San Miguel, Principe de los Angeles, Antiguo Tutelar de los Godos, y Protector de España. En Madrid: por Maria de Quiñones: a costa de Francisco de Robles..., 1643.

19 Ibídem, fol. 3. 
las iglesias de su vocación. Todavía se conservan algunos documentos impresos ese año, dando cumplimiento de la disposición real, como la Solemne inuocacion del supremo serafin S. Miguel², el Memorial dado a la Catolica Magestad del Rey... Felipe IIII'1, o la Copia de una carta que se ha embiado a diversas partes destos Reynos...", donde se lee que

"Su Magestad (Dios le guarde)... para reparar el daño que nuestros pecados causan en estos sus Reynos... elige por sumamente eficaz la proteccion del Glorioso Arcangel San Miguel...y en todas las ciudades, villas, y lugares de su Reynado, sea recibido por su Protector, y amparo el Arcangel San Miguel... 4 de Febrero, 1643"22.

A lo largo de 28 capítulos Nieremberg va recopilando todo tipo de elogios sobre el arcángel, y repitiendo la doctrina de los antiguos Padres. Y explica que el origen de su auctoritas se gestó tras su victoria sobre Lucifer, que era el serafín de mayor categoría. Al derrotarle adquirió todas sus prerrogativas y oficios, entre ellos "Capitán General de los exercitos del Señor", y también todas las dignidades, oficios, y ministerios de todos los coros angélicos. Y por eso San Miguel, en cuanto ángel, fue custodio de la Virgen. Como arcángel, fue custodio de Adán, patriarcas, reyes, profetas, apóstoles, pontífices y mártires. Como Principado, guarda de todos los Reinos y Estados de la Iglesia. Como Potestad, resiste a los demonios. Como Virtud, custodia el mundo, los astros y los planetas. Como Dominación, ejerce su señorío sobre toda la Iglesia. Como Trono, es Juez Mayor en todos los juicios. Como Querubín, revela los misterios divinos. Y como Serafín ama a Dios más que todos los ángeles.

Nieremberg no repara en títulos y honores para San Miguel, a quien adorna con los más importantes: Vice Dios, Vicario de la Santísima Trinidad, Privado de Dios, Presidente del Reino Celestial, Prefecto del Pretorio Divino, Justicia Mayor de Dios, Pretor en la Republica divina, Adelantado del Reino de Dios, Ángel de Paz, Exterminator de los demonios, Canciller del Cielo, Príncipe de los Ángeles, Custodio de la Sinagoga, Patrón y Protector de la iglesia, Alférez General de Cristo (Signífero), Gran Sacerdote, Patrón del género humano, Abogado de los hombres, y Juez de las almas. Leyendo los honores que Nieremberg atribuye

${ }^{20}$ LEÓN Y QUIRÓS Cecilio: Solemne inuocacion del supremo serafin S. Miguel...: para que assista y patrocine las armas de España... contra sus rebeldes e invasores / lo predico en la... Iglesia... metropolitana de Granada... Cecilio de Leon y Quiros... en ocho de mayo de mil y seiscientos y quarenta y tres: En Granada: por Francisco Sanchez y Baltasar de Bolibar, 1643.

${ }^{21}$ MEMORIAL dado a la Catolica Magestad de el Rey... D. Felipe III, Juan Gómez de Blas, impresor, 1643.

${ }^{22}$ COPIA de una carta que se ha embiado a diversas partes destos Reynos, exotando a la devocion del Glorioso Arcangel S. Miguel, 1643. 
a San Miguel, se entiende por qué se le representó con bastón de mando, presidiendo el desfile de ángeles en las series angélicas.

"Avía mucho que ponderar aqui, la autoridad, y dignidad que tendra san Miguel... que de los mismos Angeles se sirviesse como de criados, acompañandole, y reverenciandole con su asistencia.... Pues está entre los Angeles, como si fuera su Rei, pareciendo el Señor dellos, y ellos sus pajes. Esto deve ser ordinario, que acompañen gran numero de Angeles à san Miguel, pues dize la Iglesia: Viene Miguel Arcangel con multitud de Angeles, dando a entender la guarda, y cortejo que le hazen los Espiritus Celestiales. ${ }^{23}$ (...) Signifero... no significa qualquier Alferez de una Capitania ordinaria, sino de esquadrones, o legion entera, y para dezirlo mas claro, no significa el que llevava vandera, sino al que tenia alguna insignia principal, que fuesse divisa comun de un cuerpo del exercito"24

También Blasco de Lanuza ${ }^{25}$, el fraile benedictino que escribió el tratado más importante de la angelología barroca, nos aporta algunas claves para entender porqué el cetro era considerado también un atributo angélico. Ya en el primer capítulo de su obra advertía que la vara de mando era un atributo divino, como había comprendido el profeta Jeremías cuando Dios le mostró la visión de una vara, $\mathrm{y}$ un cetro con un ojo.

"Con este jeroglifico descubrieron los Sacerdotes Egipcios a Dios: un cetro con un ojo encima como puesto en vela, según advierte San Cyrilo, para simbolizarnos que siempre tiene el cetro de su gobierno en la mano y el ojo de su providencia atento, para acudir a la conservación, y regimiento de todo lo criado". ${ }^{26}$

Pero Lanuza entiende que la vara con que Dios vela y defiende al mundo es también un atributo angélico, que simboliza a su vez la vigilancia que ejercen los ángeles sobre el mundo y sobre la Iglesia.

"Vara de vigilantes se dize Dios, porque esta siempre con el cetro de su providencia en la mano, rigiendo, y gobernando al mundo por medio de sus Santos Angeles... La vara es figura de la virtud divina... es también símbolo del auxilio divino... es jeroglífico del gobierno, y regimiento de los Angeles, el cual tienen por comisión del Señor; por eso tenía vara aquel angel que habló a Gedeón... Y así Angel con vara es clara divisa de que tiene cometido el gobierno del mundo". ${ }^{27}$

${ }^{23}$ NIEREMBERG, Juan Eusebio: op. cit, cap. V.

${ }^{24}$ Ibidem, cap. XVI.

${ }^{25}$ BLASCO DE LANUZA, Francisco: Patrocinio de angeles y combate de demonios...: es vna ilustracion de los beneficios que hazen los Angeles de la Guarda à los hombres... I por... Fr. Francisco de Blasco Lanuza... de monges benitos claustrales...: Impresso en el Real Monasterio de San Iuan de la Peña: por Iuan Nogues, 1652.

${ }^{26}$ Ibídem, p. 6.

${ }^{27}$ Ibid., pp.7-8. 
Así que los ángeles portan varas de mando porque tienen encomendado el gobierno del mundo, y San Miguel, porque es también el Príncipe y el Capitán de los ejércitos celestiales y de la Iglesia (Figuras 10 y 11).

Fecha de recepción: 21 de septiembre de 2015.

Fecha de aceptación: 20 de noviembre de 2015.

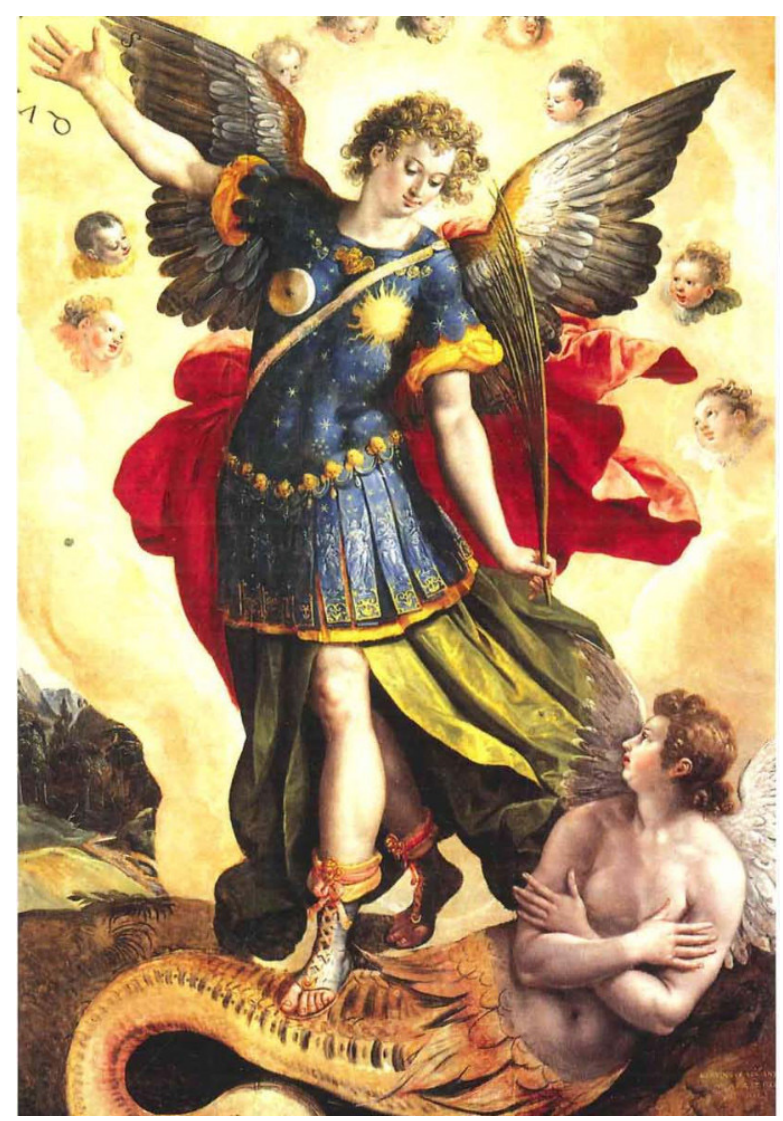

Figura 1. San Miguel arcángel. Martin de Vos. 1581. Catedral de Cuautitlán (México). 


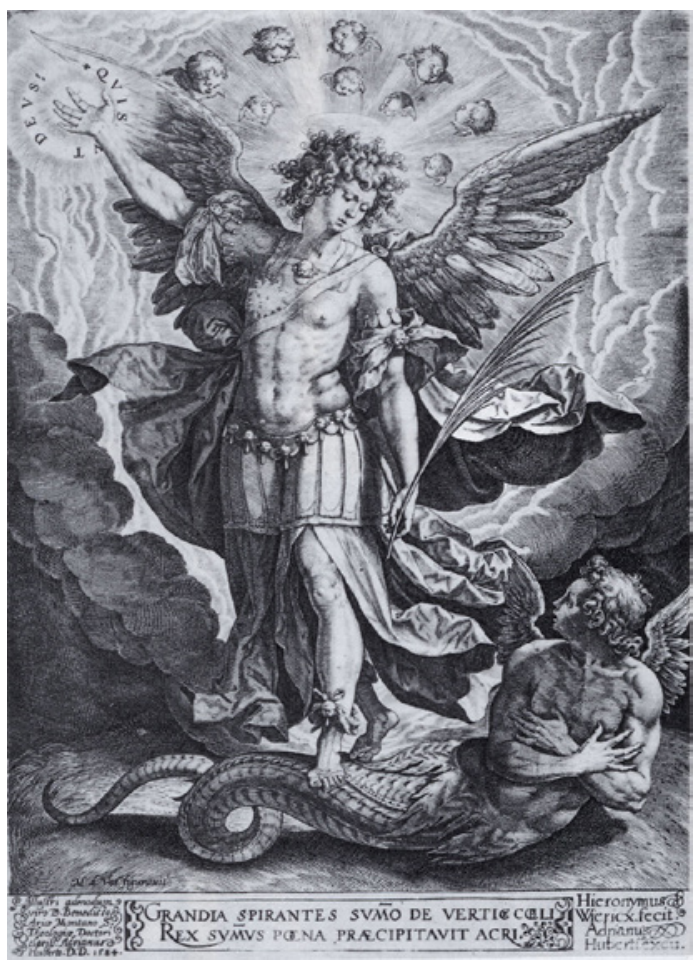

Figura 2. San Miguel arcángel. Hieronymus Wierix. Publicado por Adrianus Huberti, 1584.

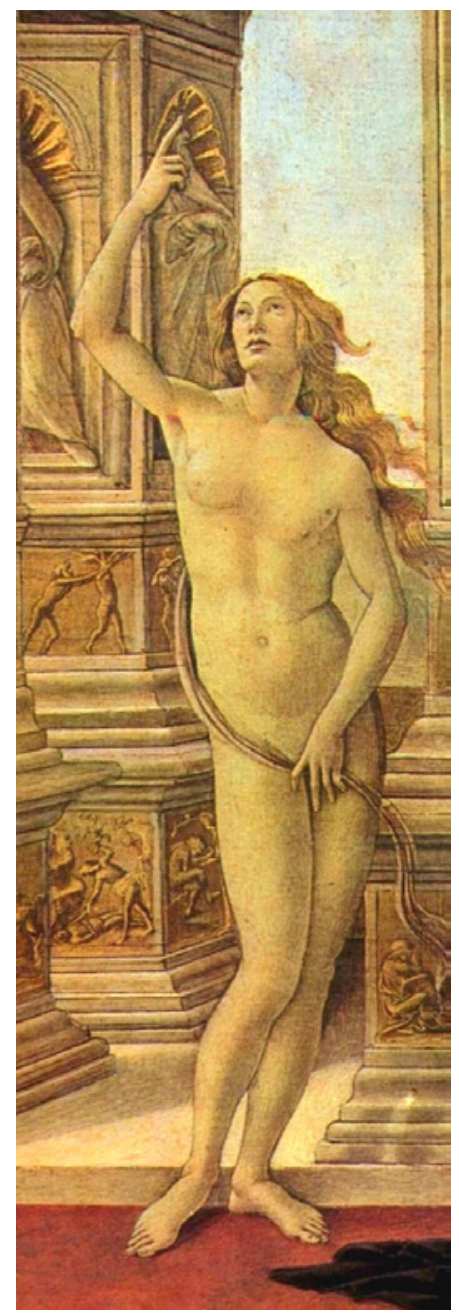

Figura 3. La Verdad. Fragmento de La calumnia de Apeles.

Botticelli. c. 1495. Galería de los Uffizi, Florencia. 
Figura 4. Sol-Apolo y Diana, Alberto Durero. c. 1500-1505, British Museum, Londres.

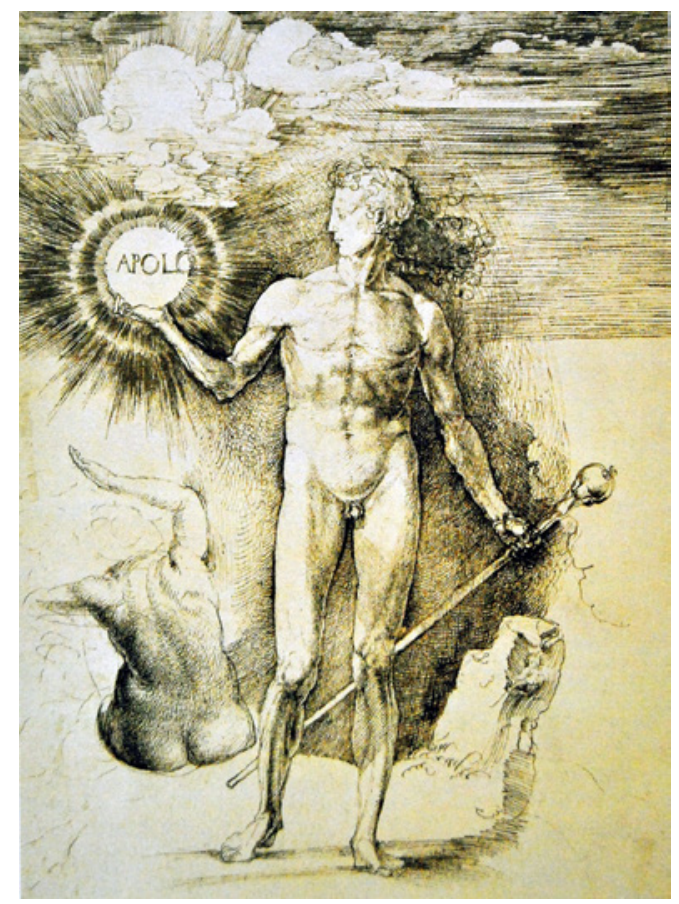

Figura 5. Verita. Iconología, Cesare Ripa. Roma, 1603, p. 500.

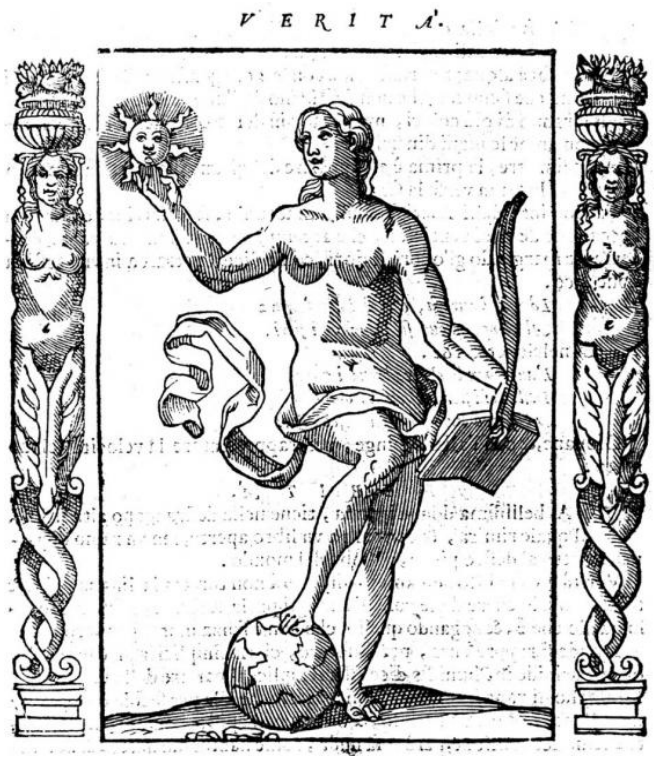

LABORATORIO DE ARTE 28 (2016), pp. 243-258, ISSN 1130-5762 e-ISSN 2253-8305 - DOI http://dx.doi.org/10.12795/LA.2006.i.01.13 

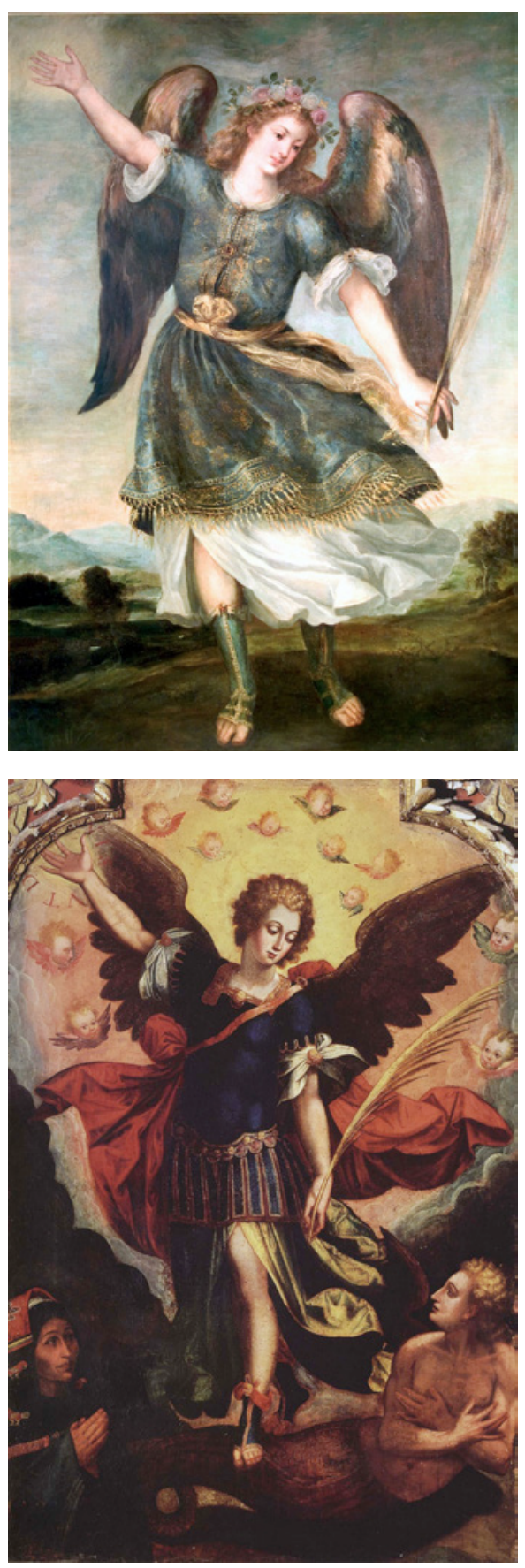

Figura 6. San Miguel arcángel. Bartolomé Román. ca. 1635. Museo Provincial de Guadalajara.
Figura 7. San Miguel arcángel. 1635-40. Iglesia de San Pedro. Lima. 


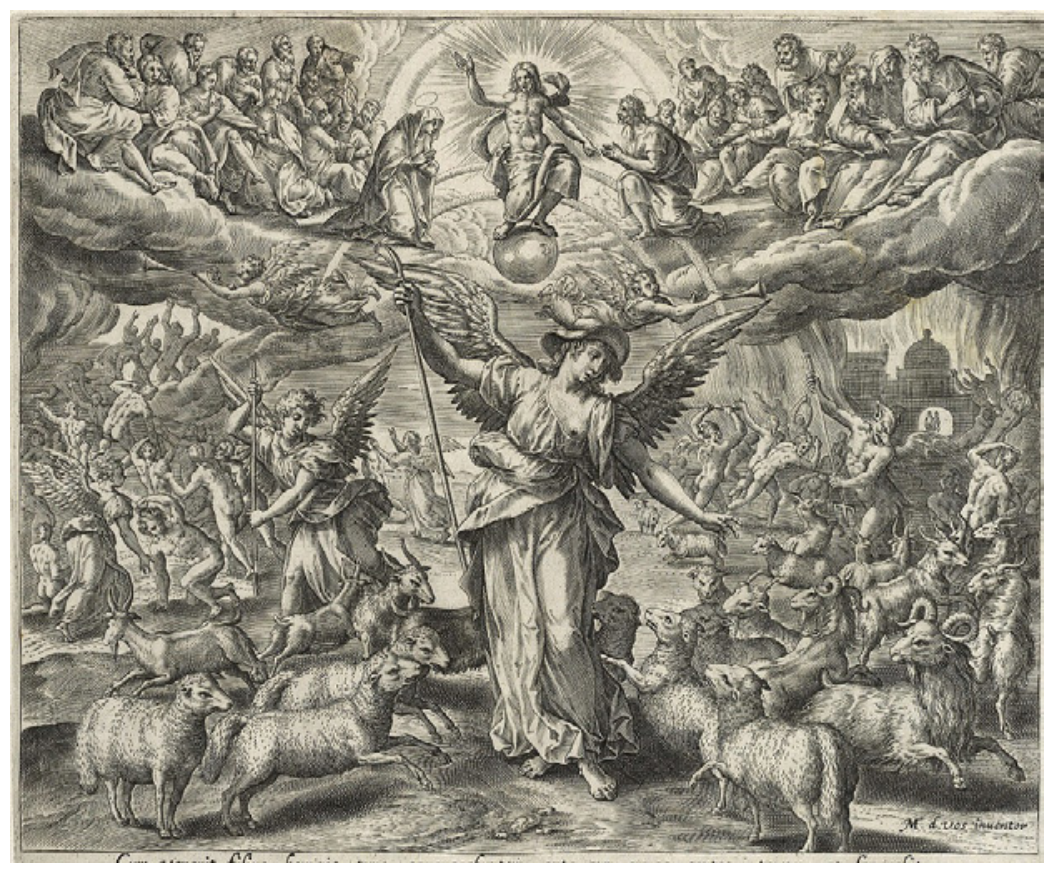

Figura 8. Juicio Final, Gerard de Jode. 1585?, sobre Martín de Vos (1570?).

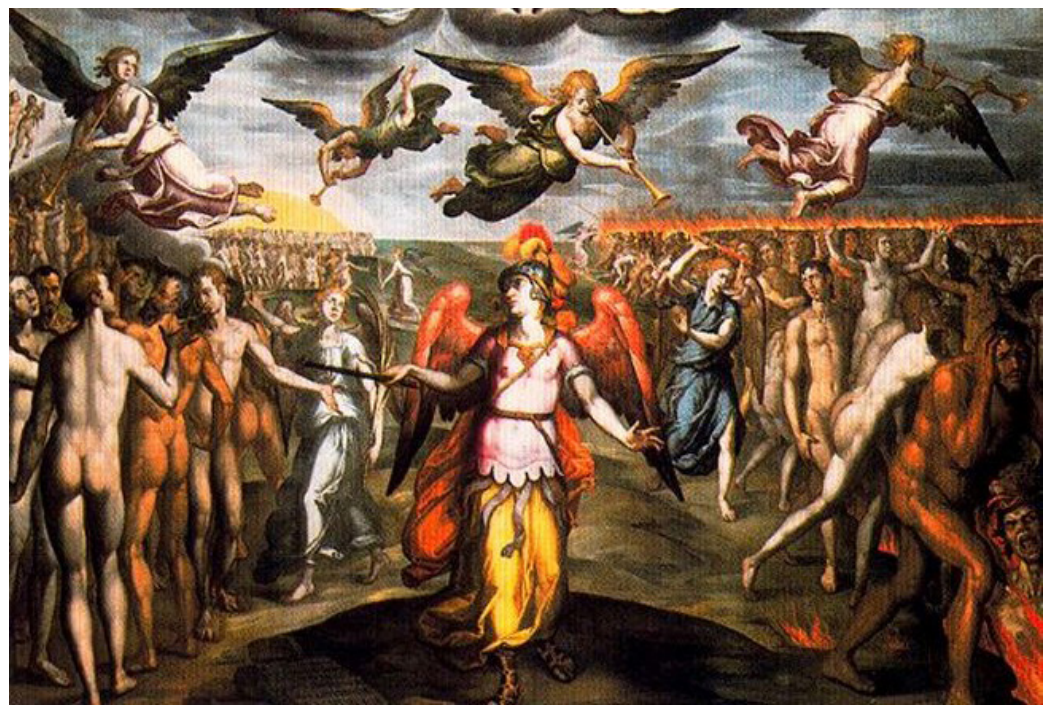

Figura 9. Juicio Final. Detalle. Francisco Pacheco. 1611. Museo Goya de Castres. 


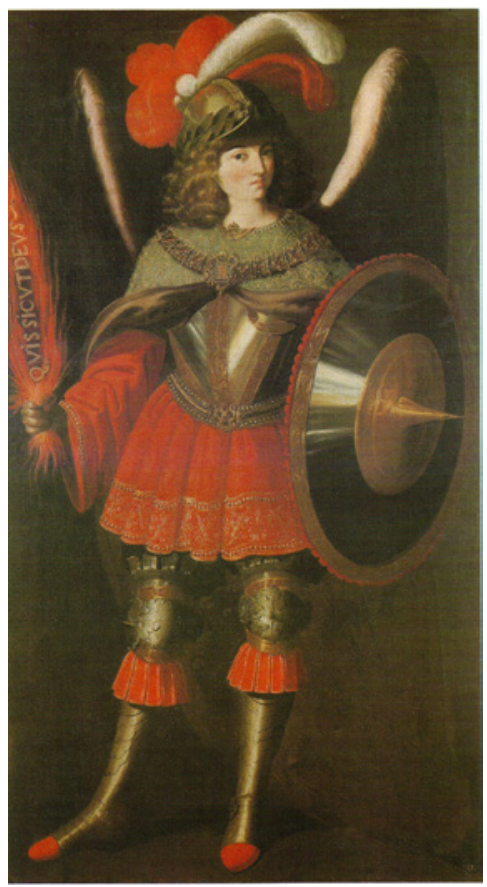

Figura 10. San Miguel arcángel. ¿Francisco de Zurbarán?, hacia 1650, Colección Banco Santander.

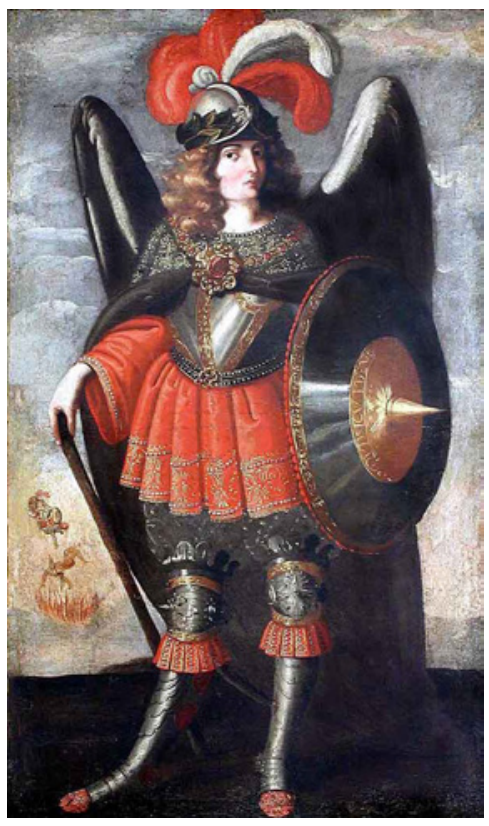

Figura 11. San Miguel arcángel. Atribuido a Ignacio de Ríes y Francisco Polanco. Escuela sevillana. $2^{\mathrm{a}}$ mitad siglo XVII. Monasterio de la Concepción. Lima (Perú). 